\title{
3-Acetoxy-fatty acid isoprenyl esters from androconia of the ithomiine butterfly Ithomia salapia
}

\author{
Florian Mann ${ }^{1}$, Daiane Szczerbowski ${ }^{1}$, Lisa de Silva², Melanie McClure ${ }^{2,3}$, \\ Marianne Elias ${ }^{2}$ and Stefan Schulz ${ }^{*}$
}

\author{
Full Research Paper \\ Address: \\ ${ }^{1}$ Institute of Organic Chemistry, Technische Universität \\ Braunschweig, Hagenring 30, 38106 Braunschweig, Germany, \\ ${ }^{2}$ Institut de Systématique Evolution Biodiversité, Centre National de la \\ Recherche Scientifique, MNHN, Sorbonne Université, EPHE, \\ Université des Antilles, 45 rue Buffon, CP 50, 75005 Paris, France \\ and ${ }^{3}$ Laboratoire Écologie, Évolution, Interactions des Systèmes \\ Amazoniens (LEEISA), Université de Guyane, CNRS, IFREMER, \\ 97300 Cayenne, France \\ Email: \\ Stefan Schulz - stefan.schulz@tu-bs.de \\ * Corresponding author

\section{Keywords:} \\ fatty acid esters; mass spectrometry; mimicry; pheromones; \\ pyrrolizidine alkaloids

\begin{abstract}
Beilstein J. Org. Chem. 2020, 16, 2776-2787.
\end{abstract} \\ https://doi.org/10.3762/bjoc.16.228 \\ Received: 31 July 2020 \\ Accepted: 27 October 2020 \\ Published: 16 November 2020 \\ Associate Editor: J. S. Dickschat \\ (C) 2020 Mann et al.; licensee Beilstein-Institut. \\ License and terms: see end of document.
}

\begin{abstract}
Male ithomiine butterflies (Nymphalidae: Danainae) have hairpencils on the forewings (i.e., androconia) that disseminate semiochemicals during courtship. While most ithomiines are known to contain derivatives of pyrrolizidine alkaloids, dihydropyrrolizines, or $\gamma$-lactones in these androconia, here we report on a new class of fatty acid esters identified in two subspecies, Ithomia salapia aquinia and $I$. s. derasa. The major components were identified as isoprenyl (3-methyl-3-butenyl) (Z)-3-acetoxy-11-octadecenoate, isoprenyl (Z)-3-acetoxy-13-octadecenoate (12) and isoprenyl 3-acetoxyoctadecanoate (11) by GC/MS and GC/IR analyses, microderivatizations, and synthesis of representative compounds. The absolute configuration of 12 was determined to be $R$. The two subspecies differed not only in the composition of the ester bouquet, but also in the composition of more volatile androconial constituents. While some individuals of $I$. s. aquinia contained ithomiolide A (3), a pyrrolizidine alkaloid derived $\gamma$-lactone, I. $s$. derasa carried the sesquiterpene $\alpha$-elemol $(\mathbf{8})$ in the androconia. These differences might be important for the reproductive isolation of the two subspecies, in line with previously reported low gene exchange between the two species in regions where they co-occur. Furthermore, the occurrence of positional isomers of unsaturated fatty acid derivatives indicates activity of two different desaturases within these butterflies, $\Delta 9$ and $\Delta 11$, which has not been reported before in male Lepidoptera.
\end{abstract}

\section{Introduction}

The Neotropical butterfly tribe Ithomiini (Nymphalidae: Danainae) is very diverse and species-rich, with over 390 species and 50 genera [1,2] and extensively involved in
Müllerian mimetic interactions [3]. Ithomiines are well suited for studies on speciation (species formation), as species often consist of multiple subspecies diverging for a number of adap- 
tive traits, such as color pattern or host plants, which can then cause reproductive isolation. As such, they offer an excellent system to study the mechanisms underlying diversification and species recognition. Yet despite growing interests in this tribe, chemical differentiation between taxa has garnered surprisingly little attention until now.

Here we focus on the two closely related taxa, Ithomia salapia aquinia and I. s. derasa. The two subspecies have somewhat divergent wing color patterns (see Supporting Information File 1, Figure S1) [4], are widely distributed, and parapatric in north-eastern Peru [5]. Despite the geographic overlap in distribution, a recent genetic study showed limited gene flow [4] Reproductive isolation in mimetic butterflies can be driven by multiple factors, notably non-random mating based on color pattern and/or sexual pheromones [6-8]. Determining whether the closely related subspecies of I. salapia differ in the chemical composition of volatiles is, therefore, of great interest.

All male ithomiine butterflies, including Ithomia, possess scent glands on their forewings, so-called androconia, covered with erectable hairpencils (Figure 1). They are used during courtship and are known to contain compounds acting as pheromones for the butterflies [2]. Adult ithomiines sequester pyrrolizidine alkaloids (PAs) pharmacophagously from various plants [9]. These alkaloids are transformed into the alkaloid and pheromone precursor lycopsamine (1, Scheme 1) [10-12] that can then be converted either into necine base derived compounds such as methyl hydroxydanaidoate (2), or into necic acids derived ones, e.g., ithomiolide A (3) [10-12]. While dihydropyrrolizines are also used by other Lepidoptera, e.g., danaines [13-15] or arctiines [16,17], $\gamma$-lactones derived from necic acids are specific to ithomiines of more derived taxa [11].

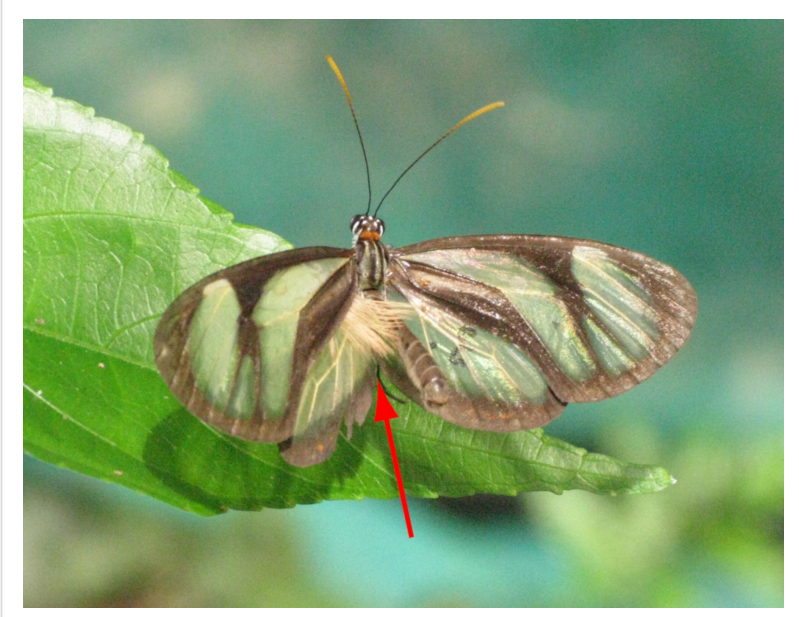

Figure 1: Extended hairs (arrow) of the androconia of a male Ithomia salapia aquinia (Photo: Melanie McClure).

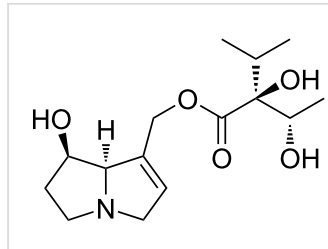

1

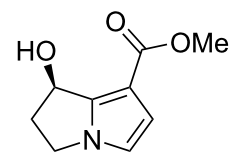

2

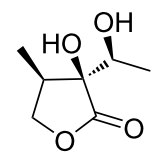

3
Scheme 1: Pyrrolizidine alkaloid lycopsamine (1) and the putative pheromone compounds methyl hydroxydanaidoate (2) and ithomiolide A (3).

Past studies of the androconia of Ithomia have reported the presence of $\mathbf{3}$ in Ithomia iphianassa from Venezuela [10] and in I. salapia salapia from Ecuador [11], whereas no PA-derived compounds were found in any Ithomia spp. including I. agnosia agnosia [11]. Information on non-PA derived compounds in the androconia of ithomiines is mostly lacking, although we recently described ( $Z$ )-9-hydroxy-6-nonenoic acid and derivatives including dimers and fatty acid conjugates as major constituents of the androconia of Oleria onega [18].

Here we report on the chemical composition of the androconia of Ithomia salapia aquinia and I. s. derasa. A new type of butterfly scent gland constituents, acylated isoprenyl esters of fatty acids, is described, representing a combination of fatty acid and terpene biosynthesis. We also reveal small but reproducible differences between the two subspecies that could potentially be involved in species recognition and reproductive isolation.

\section{Results}

Extracts from the wing androconia of $I$. s. derasa and I. s. aquinia were analyzed by GC/MS. The extracts consisted predominately of fatty acid esters with few other compounds (Table 1). While most ithomiines possess PA-derivatives in the androconia $[10-12,18,19]$, only two of the five samples of I. s. aquinia contained small amounts of ithomiolide A (3), whereas PA derivatives were entirely absent in I. s. derasa.

In contrast, the sesquiterpene $\alpha$-elemol (8) was exclusively present in all tested individuals of $I$. $s$. derasa, together with some related minor sesquiterpenes. This sesquiterpene alcohol is likely formed from hedycaryol (7) during GC/MS analysis by a Cope-rearrangement $[20,21]$, indicating that 7 might be originally present in the hairpencils. That said, we cannot disprove that this rearrangement could also occur in the androconia. Hedycaryol is an early product of sesquiterpene biosynthesis, formed by a 1,10-cyclization of the farnesyl cation 5 obtained from farnesyl pyrophosphate (4) (Scheme 2). Trapping the cation 6 with water leads to 7, which in turn might rearrange into 8 [22]. 
Table 1: Compounds found in extracts of the androconia of Ithomia salapia derasa and $I$. salapia aquinia. Five individuals of each subspecies were analyzed. Only compounds occurring at least in two individuals of a subspecies are listed. The peak group refers to compounds eluting closely together. The number before the colon indicates the number of individuals carrying this compound, followed by the range of the relative amount.

\begin{tabular}{|c|c|c|c|c|c|}
\hline No & Compound & Peak group & Retention index & I. salapia derasa & I. salapia aquinia \\
\hline 1 & ithomiolide A (3) & & 1219 & - & 2: $1.91-2.64$ \\
\hline 2 & $\beta$-elemene & & 1388 & 4: $0.01-0.19$ & - \\
\hline 3 & elemol/hedycaryol isomer & & 1517 & 3: $0.02-0.06$ & - \\
\hline 4 & $\alpha$-elemol (8) & & 1554 & 5: $0.11-2.88$ & - \\
\hline 5 & elemol/hedycaryol isomer & & 1662 & 3: $0.01-0.02$ & - \\
\hline 6 & hexadecenoic acid & & 1942 & - & 3: $0.55-5.76$ \\
\hline 7 & hexadecanoic acid & & 1961 & $3: 0.02-0.25$ & 3: $0.28-12.88$ \\
\hline 8 & 7-heneicosene & & 2081 & 3: $0.15-13.97$ & - \\
\hline 9 & heneicosane & & 2100 & $3: 0.02-0.54$ & - \\
\hline 10 & octadecenoic acid & & 2144 & $4: 0.62-3.69$ & 2: $1.02-7.88$ \\
\hline 11 & isoprenyl 9-hexadecenoate & $A$ & 2233 & - & 3: $0.01-0.33$ \\
\hline 12 & isoprenyl 11-hexadecenoate & $A$ & 2244 & - & 5: 0.32-2.02 \\
\hline 13 & isoprenyl hexadecanoate & A & 2258 & - & 5: $0.11-2.24$ \\
\hline 14 & tricosane & & 2300 & 5: $0.01-0.44$ & 3: $001-0.11$ \\
\hline 15 & 11-methyltricosane & & 2335 & $4: 0.06-4.04$ & 5: $0.02-0.89$ \\
\hline 16 & eicosenoic acid & & 2360 & 3: $0.08-0.96$ & - \\
\hline 17 & isoprenyl octadecadienoate & B & 2431 & $4: 0.01-0.30$ & - \\
\hline 18 & isoprenyl 9-octadecenoate (10) & B & 2444 & 5: $0.36-8.27$ & 5: $0.01-12.19$ \\
\hline 19 & isoprenyl 11-octadecenoate & B & 2455 & 2: $0.01-0.02$ & $4: 0.01-0.33$ \\
\hline 20 & isoprenyl octadecanoate & B & 2463 & 5: $0.01-0.32$ & 3: $0.01-0.07$ \\
\hline 21 & isoprenyl 3-acetoxy-11-hexadecenoate & B & 2481 & 5: $0.10-0.40$ & 5: $0.01-0.42$ \\
\hline 22 & isoprenyl 3-acetoxyhexadecanoate & B & 2491 & 5: $0.30-1.32$ & 5: $0.76-4.93$ \\
\hline 23 & pentacosane & B & 2500 & 5: $0.01-0.13$ & 3: $0.01-0.10$ \\
\hline 24 & isoprenyl $(2 E, 11 Z)-2,11$-octadecadienoate & B & 2506 & 4: $0.14-12.63$ & $4: 0.16-0.89$ \\
\hline 25 & isoprenyl $(2 E, 13 Z)-2,13$-octadecadienoate & B & 2516 & $4: 0.01-0.92$ & $4: 0.13-0.38$ \\
\hline 26 & isoprenyl $(E)$-2-octadecenoate & B & 2523 & 5: $0.04-1.96$ & $4: 0.18-0.56$ \\
\hline 27 & 11- and 13-methylpentacosane & & 2535 & 3: $0.02-0.05$ & 2: $0.01-0.03$ \\
\hline 28 & isoprenyl 3-hydroxy-11-octadecenoate & C & 2603 & 5: $1.10-5.02$ & - \\
\hline 29 & isoprenyl 3-hydroxy-13-octadecenoate (24) & C & 2622 & 5: $0.07-0.40$ & 2: $0.03-0.05$ \\
\hline 30 & isoprenyl 3-hydroxyoctadecanoate & C & 2626 & 5: $0.98-2.41$ & - \\
\hline 31 & isoprenyl (Z)-3-acetoxy-11-octadecenoate & $\mathrm{D}$ & 2678 & 5: $22.72-45.28$ & 5: $14.58-41.42$ \\
\hline 32 & isoprenyl (Z)-3-acetoxy-13-octadecenoate (12) & D & 2692 & 5: $3.87-14.67$ & $5: 2.38-30.43$ \\
\hline 33 & isoprenyl 3-acetoxyoctadecanoate (11) & $\mathrm{D}$ & 2698 & 5: $16.01-25.44$ & $5: 26.20-43.73$ \\
\hline 34 & isoprenyl 3-hydroxy-13-eicosenoate & & 2808 & $2: 0.01-0.45$ & - \\
\hline 35 & isoprenyl 3-acetoxy-13-eicosenoate & E & 2874 & $5: 4.25-6.81$ & 5: $0.01-1.20$ \\
\hline 36 & isoprenyl 3-acetoxyeicosanoate & $E$ & 2891 & $5: 0.02-0.35$ & 3: $0.01-0.52$ \\
\hline
\end{tabular}

The fatty acid ester composition also differed between the two subspecies (Figure 2). Based on their elution order, five groups of compounds were detected, labelled A-E in Table 1. Groups $A$ and $B$ consisted of saturated and unsaturated $C_{16}$ and $C_{18}$ pentenyl esters. These compounds proved to be 3-methyl-3butenyl esters, which were previously reported in bees [23,24]. Biosynthetically the alcohol part seems to originate from the terpene building block 3-methyl-3-butenyl (isoprenyl) pyrophosphate. Because isoprenyl pyrophosphate is partly converted to 3-methyl-2-butenyl (prenyl) pyrophosphate during terpene biosynthesis, the presence of prenyl esters could not be excluded. Nevertheless, the two ester types can be readily distinguished by EIMS. While 3-methyl-3-butenyl esters of saturated acids have a dominating ion at $\mathrm{m} / \mathrm{z} 68$, 3-methyl-2butenyl esters show a peak pair $\mathrm{m} / \mathrm{z} 68$ and 69 of similar intensity (see Supporting Information File 1, Figure S2), as reported earlier [24]. This difference in the spectra can be explained by the different stabilization of the respective ions (Figure 3 ). The abundance of $\mathrm{m} / \mathrm{z} 68$ is higher in isoprenyl esters due to the more stable allyl radical cation (Figure 3A). In contrast, prenyl 
<smiles>CC(C)=CCC/C(C)=C/CC/C(C)=C/COP(=O)(O)OP(=O)([O-])[O-]</smiles>

4<smiles>C[TeH][Po]</smiles><smiles>CC1=CCCC(C)=C1OCCCC(C)C</smiles>

5<smiles>CC1=C2CCC=C3CCC(C(C)C)C(C1)C3C2</smiles>

6<smiles>C=C[C@]1(C)CCC(C(C)(C)O)CC1C(=C)C</smiles>

8 $+\mathrm{H}_{2} \mathrm{O}$

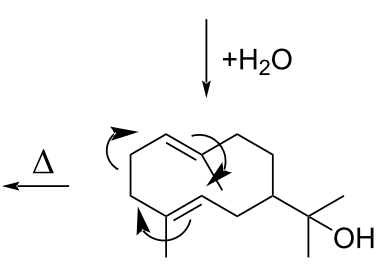

7
Scheme 2: Biosynthetic formation of hedycaryol (7) and $\alpha$-elemol (8).

ester fragmentation produces a stabilized allyl cation $\mathrm{m} / \mathrm{z} 69$ (Figure 3B), while isoprenyl esters form a less stable homoallyl cation. This situation changes when a double bond is present in the acid part. In both isoprenyl (9) and prenyl esters (10) ion $\mathrm{m} / \mathrm{z} 69$ becomes the base peak, but the proportion of $\mathrm{m} / \mathrm{z} 68$ is higher in the former esters (Figure 4). Other significant differences can be found in the region around the acylium ions. Monounsaturated prenyl esters show the elimination of $\mathrm{C}_{5} \mathrm{H}_{10}$ (M - 70, $\mathrm{m} / \mathrm{z} 280$ in A), likely formed by rearrangement of an allylic $\mathrm{H}$ to the carbonyl group, followed by H-transfer (Figure 3C). Furthermore, the prenyl group can be lost (M - 69, $\mathrm{m} / \mathrm{z} 281$ ) and the acylium ion $\mathrm{m} / \mathrm{z} 263$ is formed. In contrast, isoprenyl esters lack the $\mathrm{M}-69$ ion, but additionally show acylium +1 and +2 ions $(m / z 264$ and 265 in A).

The location of the double bonds in the unsaturated esters was determined by dimethyl disulfide (DMDS) addition [25,26]. Because the double bond in the isoprenyl side chain would likely interfere, the esters were first transformed into the respective methyl esters via a microreaction with $\mathrm{NaOMe} \mathrm{[27].} \mathrm{The}$ following DMDS derivatization revealed the presence of two isomers of each chain length, 9- and 11-hexadecenoate, as well as 9- and 11-octadecenoate (Supporting Information File 1, Table S1). Therefore, groups A and B consisted predominately of isoprenyl esters of saturated and unsaturated $\mathrm{C}_{16^{-}}$and $\mathrm{C}_{18^{-}}$ acids.

Major components of both subspecies were group D compounds. The peak pair $\mathrm{m} / \mathrm{z} 68 / 69$ including the prominent base peak indicated again isoprenyl esters. The mass spectrum of the saturated compound showed a small putative $\mathrm{M}^{+\cdot}$ ion at $\mathrm{m} / \mathrm{z} 410$

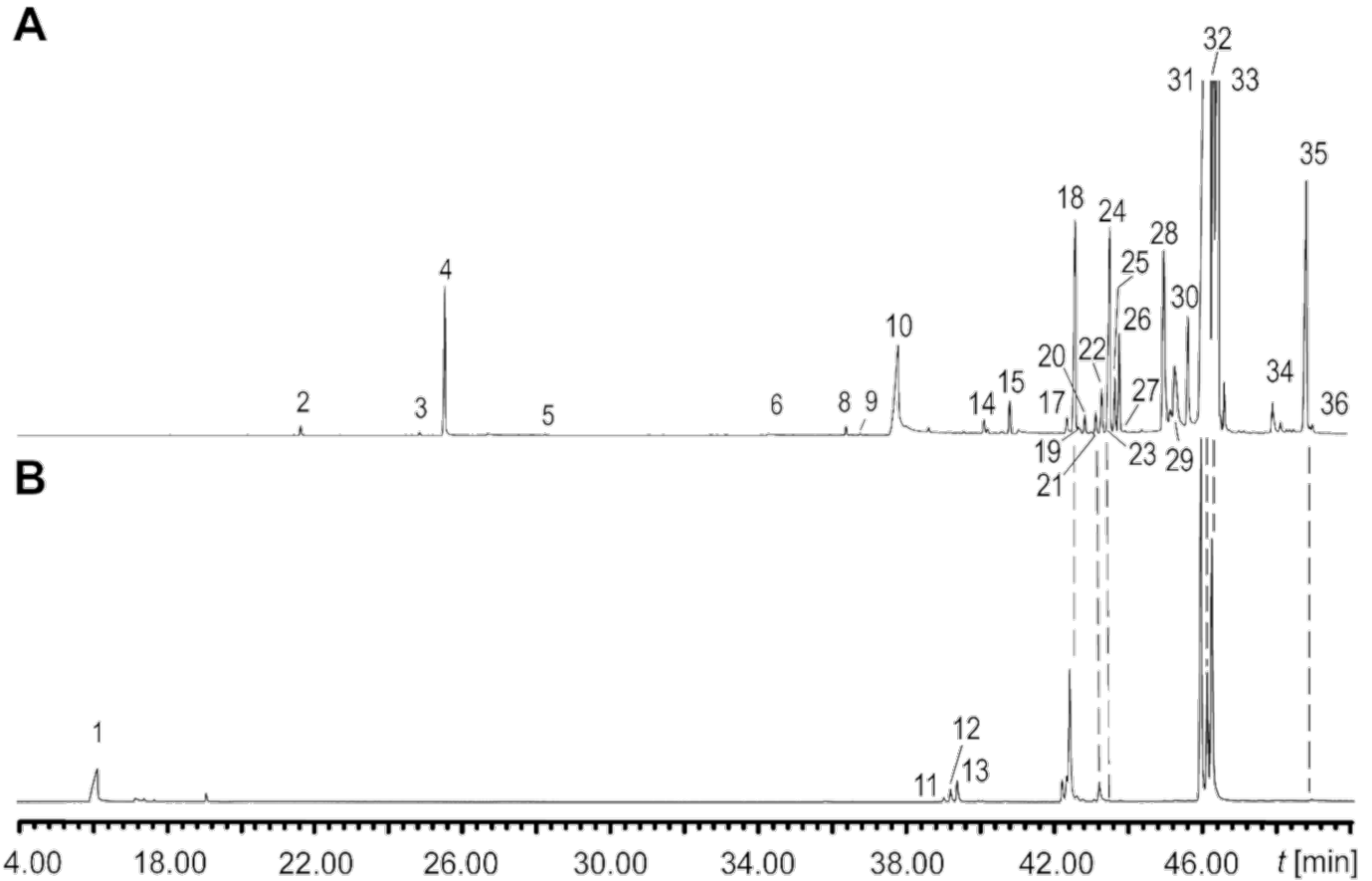


A

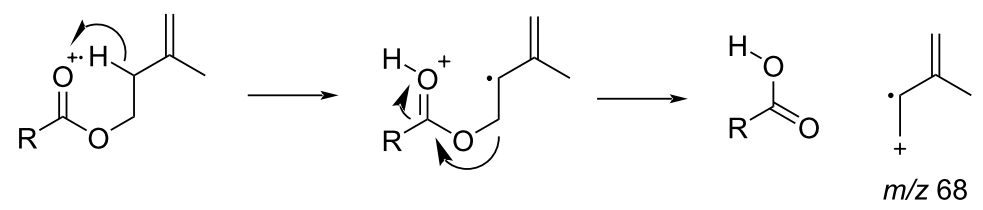<smiles>[R]C1=[O+]CCC(=C(C)C)CO1</smiles>

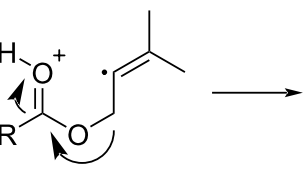<smiles>[R]C(=O)O</smiles><smiles>[CH+]C=C(C)C</smiles>

B<smiles>[R]C(=O)[O-]</smiles><smiles>[R16][CH+]C=C(C)C</smiles>

C

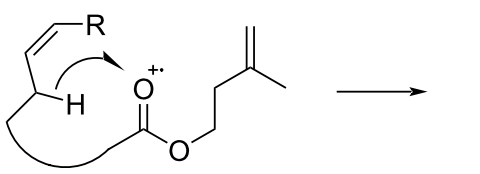

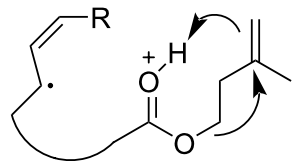<smiles>[R]/C=C\CCCCCC(=O)[OH+]</smiles><smiles>CC1(C)CC1</smiles><smiles>[R]C[O+]=C1CCCCC2C=CCC(CC=C(C)C)C1C2</smiles><smiles>[R]C=CCCCCC(OCC)=[O+][C-]1CCCCC1(C)C</smiles><smiles>[R]/C=C\CCCCCC(=O)[OH+]</smiles><smiles>CC1(C)CC1</smiles>

$m / z 280$

Figure 3: Proposed mass spectrometric formation of characteristic ions in prenyl and isoprenyl esters. Formation of $m / z 68$ (A), $\mathrm{m} / \mathrm{z} 69$ (B), and $\mathrm{m} / \mathrm{z}$ 280 (C).

and $m / z 408$ for the unsaturated analogs (Figure 5). A loss of $59 / 60 \mathrm{amu}$ from $\mathrm{M}^{+\cdot}$ suggested an acetoxy group located somewhere along the chain. The position could not be derived from the mass spectrum. Nevertheless, the transesterified sample discussed before contained methyl hydroxyalkanoates, which allowed easy location of the hydroxy-group position by GC/MS [28]. The ion $\mathrm{m} / \mathrm{z} 103$ in the spectra of the three dominating acids confirmed the location of the acetoxy group at C-3 (see Supporting Information File 1, Figure S3). The positions of the double bonds in the methyl esters were determined by DMDS derivatization. The prominent ions present in these adducts allowed the localization of the double bonds in the natural products. Surprisingly, double bonds were found at C-11 and C-13, deducible by the ions $\mathrm{m} / z 145\left(\left[\mathrm{CH}_{3} \mathrm{SC}_{7} \mathrm{H}_{14}\right]^{+}\right), 261$ $\left(\left[\mathrm{CH}_{3} \mathrm{CO}_{2} \mathrm{C}_{11} \mathrm{H}_{22} \mathrm{SCH}_{3}\right]^{+}\right), 243\left(261-\mathrm{H}_{2} \mathrm{O}\right)$, as well as 213
(261 $-\mathrm{H}_{2} \mathrm{O}-\mathrm{CH}_{2} \mathrm{O}$ ), and $\mathrm{m} / z 117\left(\left[\mathrm{CH}_{3} \mathrm{SC}_{5} \mathrm{H}_{10}\right]^{+}\right), 289$ $\left(\left[\mathrm{CH}_{3} \mathrm{CO}_{2} \mathrm{C}_{13} \mathrm{H}_{26} \mathrm{SCH}_{3}\right]^{+}\right), 271\left(289-\mathrm{H}_{2} \mathrm{O}\right)$ as well as 241 (289- $\mathrm{H}_{2} \mathrm{O}-\mathrm{CH}_{2} \mathrm{O}$ ), respectively (see Supporting Information File 1, Figure S4). An isomer with a C-9 double bond present in the simple isoprenyl esters was not detected. The configuration of the double bonds was confirmed to be $(Z)$ as expected, because GC-DD-IR analyses showed a characteristic C-H stretch band at $3004 \mathrm{~cm}^{-1}$ (see Supporting Information File 1, Figure S9) [29,30]. As such, group D consisted of isoprenyl esters of 3-acetoxy- $\mathrm{C}_{18}$-fatty acids, a group of compounds not described before in nature. To confirm this, representative isomers were synthesized as outlined below.

Isoprenyl 3-acetoxyoctadecanoate (11) was synthesized according to Scheme 3. Hexadecanol (13) was oxidized to hexade- 


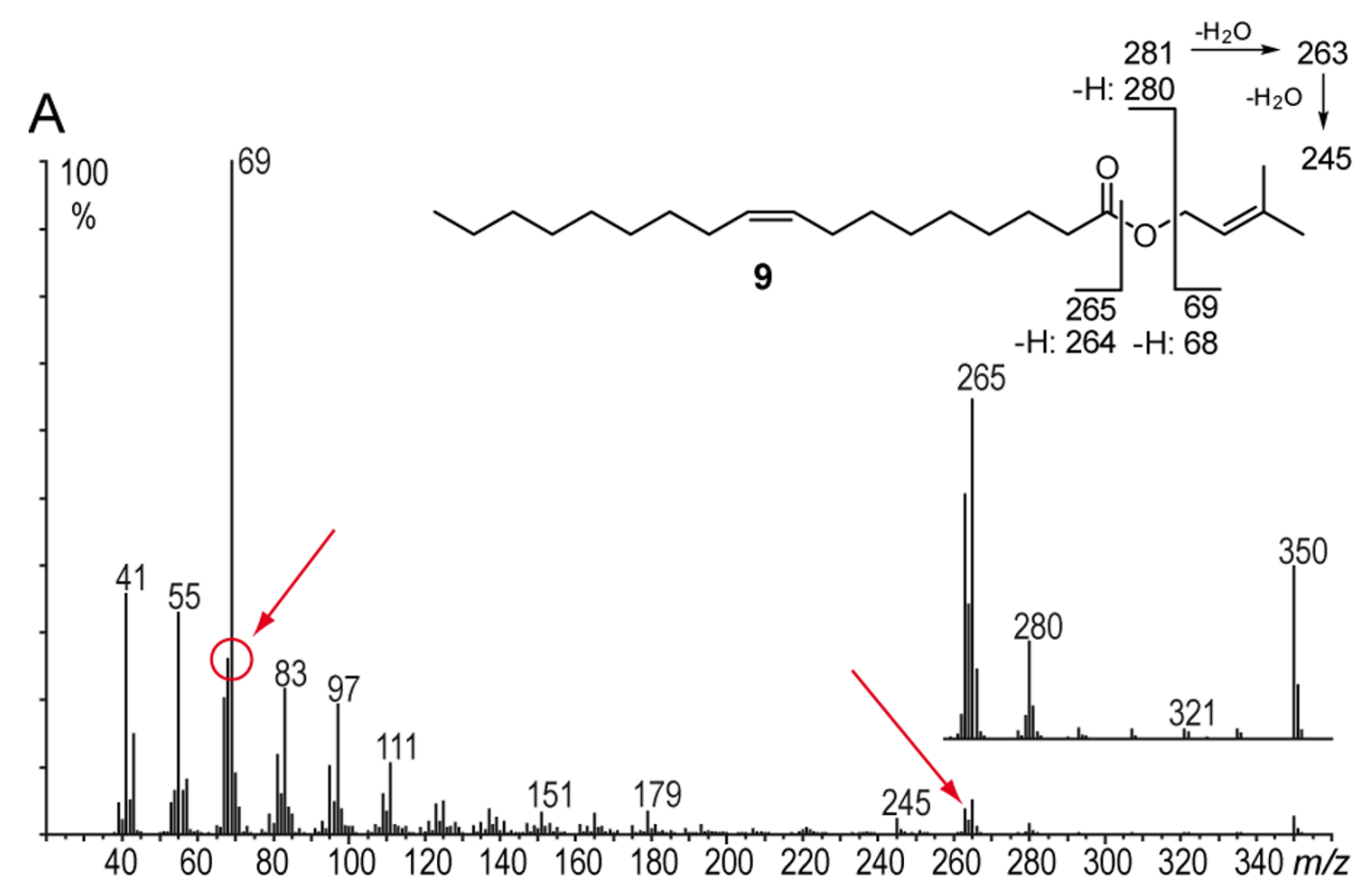

B

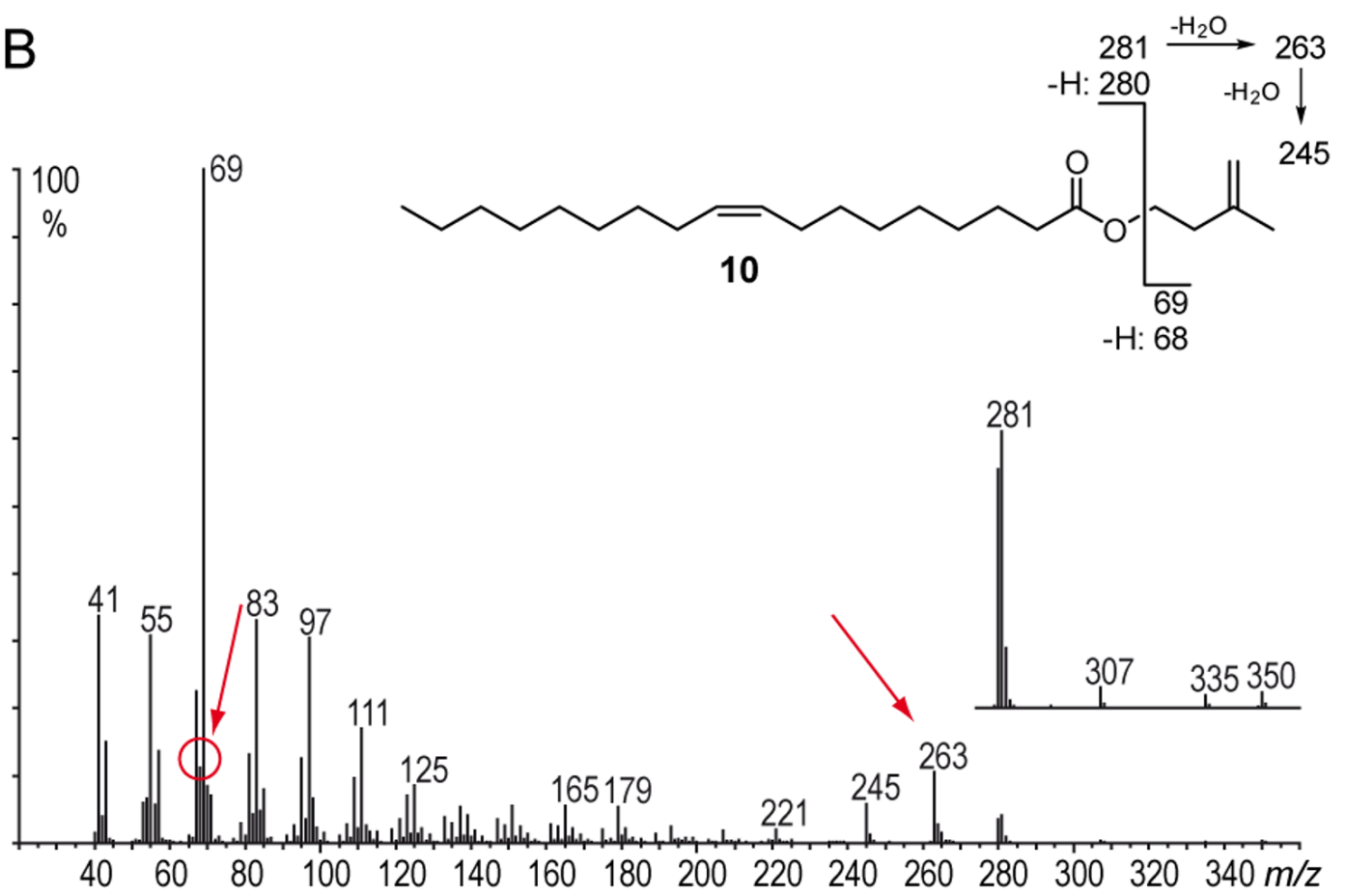

Figure 4: Mass spectra and fragmentation of A: isoprenyl (3-methyl-3-butenyl) 9-octadenoate (9) and B: prenyl (3-methyl-2-butenyl) 9-octadecenoate (10). Red arrows show characteristics in the mass spectra differentiating prenyl and isoprenyl esters.

canal (14) using $o$-iodoxybenzoic acid (IBX) [31]. The resulting aldehyde was transformed into $\beta$-ketoacid 16 with ethyl diaazoacetate and $\mathrm{SnCl}_{2}$ [32], which upon reduction with $\mathrm{NaBH}_{4}$ in methanol delivered methyl 3-hydroxyoctadecanoate
(17). Transesterification was performed with 3-methyl-3-buten1-ol using distannoxan catalysis [33]. Final acetylation of the hydroxy esters delivered the target compound isoprenyl 3-acetoxyoctadecanoate (11). Comparison of mass spectra and 


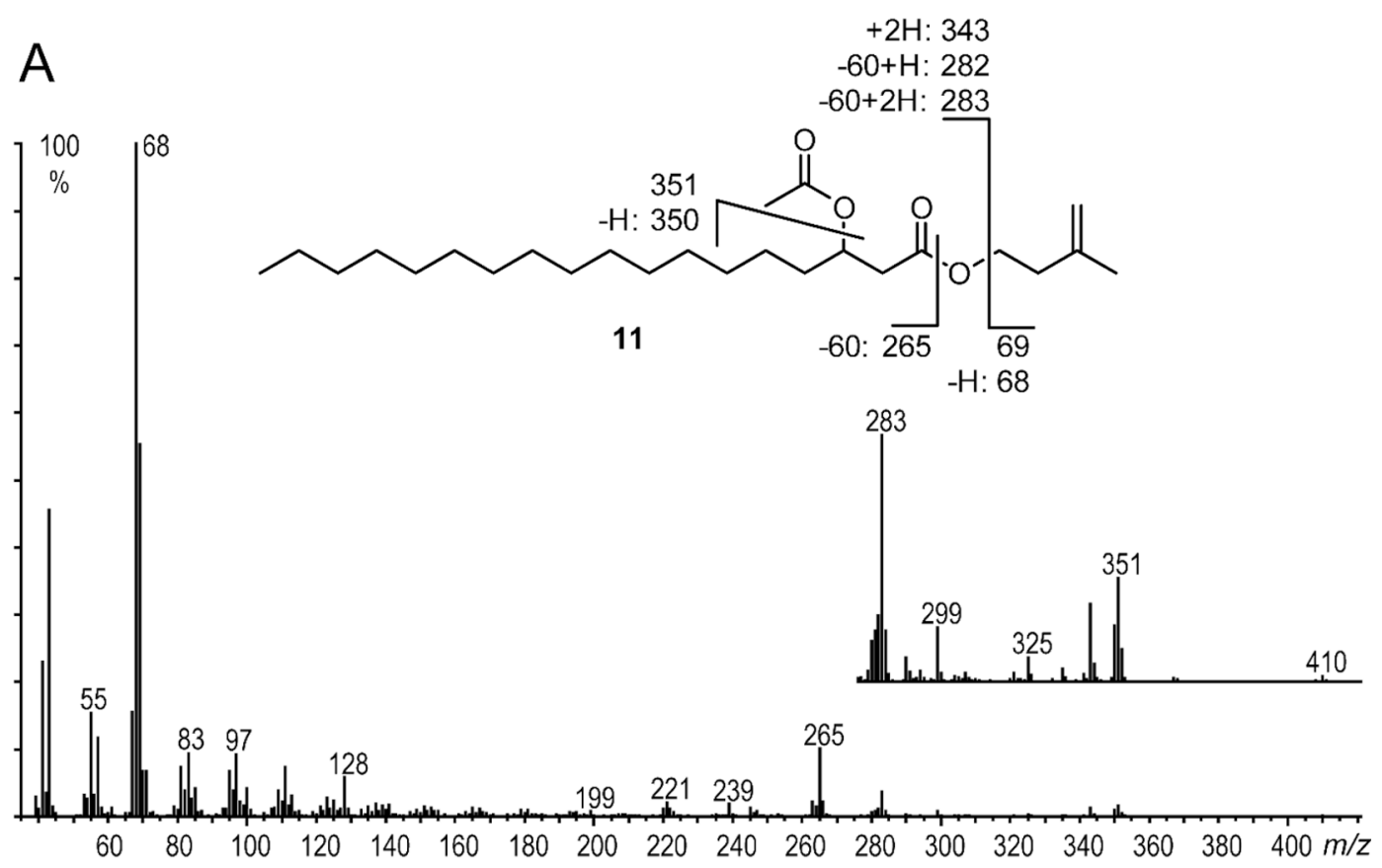

B

-60: 279

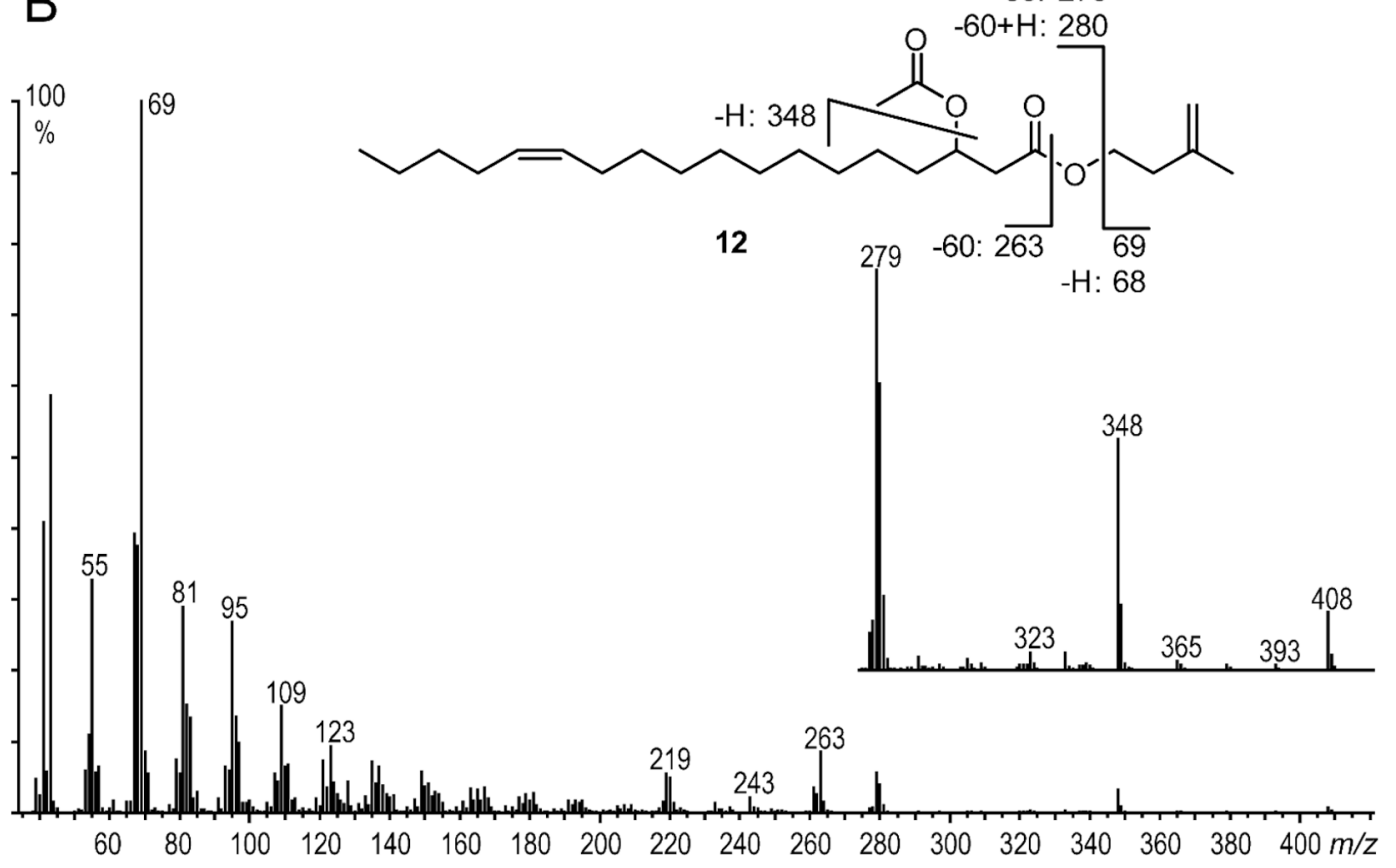

Figure 5: Mass spectra and fragmentation of A: isoprenyl 3-acetoxyoctadecanoate (11); B: isoprenyl (Z)-3-acetoxy-13-octadecenoate (12).

retention index confirmed the identity of the naturally occurring compound and $\mathbf{1 1}$.

An enantioselective synthesis of isoprenyl ( $Z$ )-3-acetoxyoctadec-13-enoate (12) was performed to verify the structural proposal and to determine the absolute configuration of the natural product (Scheme 4). The commercially available epoxide $(S)$-22 served as chiral starting material. 1,9-Nonanediol (19) was monobrominated and oxidized with IBX to yield 9-bromononanal (20). A Wittig reaction with pentylphosphonium bromide resulted in bromoalkene 21 in a 9:1 Z/E-mixture. In the following step, the Grignard reagent of $\mathbf{2 1}$ was converted into the respective Gilman cuprate with $\mathrm{Cu}(\mathrm{I}) \mathrm{I}$ for the selective reaction with the epoxide function of $(S)-22$ [34]. The hydroxy- 


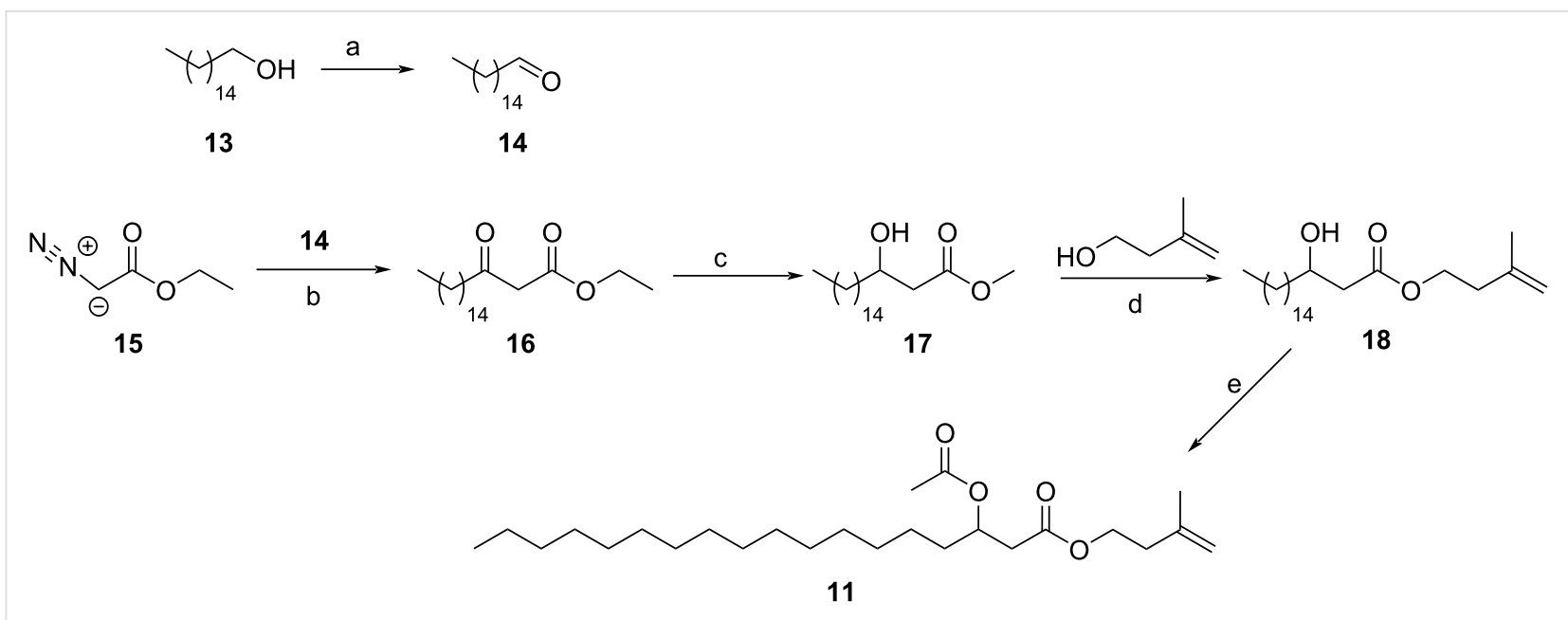

Scheme 3: Synthesis of isoprenyl 3-acetoxyoctadecanoate (11). a) IBX, EtOAc, $60{ }^{\circ} \mathrm{C}, 3.15 \mathrm{~h}, 99 \%$; b) $\mathrm{SnCl}_{2}, \mathrm{CH}_{2} \mathrm{Cl}_{2}, \mathrm{rt}, 70 \%$; c) $\mathrm{NaBH}_{4}, 12 \mathrm{~h}, 98 \%$; d) $\mathrm{SnOBu}_{2}, 140^{\circ} \mathrm{C}, 36 \mathrm{~h}, 78 \%$; e) $\mathrm{Ac}_{2} \mathrm{O}$, pyridine, DMAP, $\mathrm{CH}_{2} \mathrm{Cl}_{2}, 12 \mathrm{~h}$ rt, $67 \%$.<smiles>[R10]C[C@H](CCCCCCCCC/C=C/CCCC)OC(C)=O</smiles>

Scheme 4: a) $48 \% \mathrm{HBr}_{\text {aq }}$, toluene, $24 \mathrm{~h}, 110{ }^{\circ} \mathrm{C}, 79 \%$; b) IBX, EtOAc, $60{ }^{\circ} \mathrm{C}, 3.15 \mathrm{~h}, 90 \%$; c) $\mathrm{C}_{5} \mathrm{H}_{11} \mathrm{PPh}_{3} \mathrm{Br}, \mathrm{LDA}, \mathrm{THF},-78{ }^{\circ} \mathrm{C}, 12 \mathrm{~h}, 84 \%$; d) i) $\mathrm{Mg}$, 21, THF, ii) (S)-22, Cu(I)I, THF, $-30^{\circ} \mathrm{C}, 12 \mathrm{~h}, 79 \%$; e) $\mathrm{SnOBu}_{2}, 140^{\circ} \mathrm{C}, 36 \mathrm{~h}, 65 \%$; f) $\mathrm{Ac}_{2} \mathrm{O}$, pyridine, DMAP, $\mathrm{CH}_{2} \mathrm{Cl}_{2}, 12 \mathrm{~h} \mathrm{rt}, 74 \%$.

ester 23 was obtained in good yield. The following stannoxane induced transesterification and the final acetylation procedure delivered 12. The two isomeric natural 3-acetoxyoctadecenyl esters had retention indices of 2678 and 2692, respectively, while synthetic $\mathbf{1 2}$ showed an $I$ of 2688 . Therefore, the second eluting ester is isoprenyl ( $Z$ )-3-acetoxy-13-octadecenoate, while the earlier eluting one is the 11 -isomer.

With optically active material in hand, the absolute configuration of $\mathbf{1 2}$ was determined by enantioselective gas chromatography. Because direct separation of the large esters seemed to be difficult because of the high elution temperatures needed, we reasoned that the respective methyl 3-hydroxy esters would be much better suited, given the well-known separability of these compounds by chiral GC [35]. Therefore, a natural extract of the androconia and synthetic $(R)-\mathbf{1 2}$ were transesterified with $\mathrm{NaOMe}$ as described above to yield methyl 3-hydroxyoctade- cenoates. A synthetic sample of rac-12 obtained from $r a c-22$ was also at hand. The analysis showed that only $(R)-\mathbf{1 2}$ occurs naturally (Figure 6). Furthermore, the $(Z)$-configuration of the double bond was confirmed, because the minor amount of the (E)-isomer, present in the synthetic sample, did not coelute with the natural sample. Although only the configuration of natural 12 was determined to be exclusively $(R)$, it seems likely that the other 3-acetoxy esters also show this configuration.

Group E compounds represented bishomologs of 12, isoprenyl eicosanoate and isoprenyl 13-eicosenoate, determined by DMDS derivatization. Next to these major esters, minor amounts of related esters occurred in some samples. These include deacylated 3-hydroxy esters, isoprenyl 3-hydroxyoctadecenoates and 3-hydroxyoctadecanoate, occurring in group C. Finally, respective elimination products, e.g., isoprenyl 2,11octadecadienoate and isoprenyl 2-octadecenoate occurred in 
position of the double bonds in the acyl chain of the esters can be explained by a biosynthetic pathway described in detail in Scheme 5. The double bond distribution is consistent with both desaturases acting on palmitic acid, leading to the respective hexadecenoic acids. These acids are the starting material for an additional elongation cycle of the fatty acid biosynthesis, leading en route to 3-hydroxy- and 2-alkenoic acids and finally to 11- and 13-octadecenoic acids. While the latter free acid was not observed, 9-octadecenoic acid was also present, formed likely by action of the $\Delta 9$-desaturase on stearic acid.

3-Acetoxylated fatty acid esters are rarely found as natural products. Ethyl (S)-3-acetoxyeicosanoate and longer analogs are produced by the plant Schizolaena hystrix [46], but similar compounds from insects are unknown. Related are cactoblastins used as trail-following pheromones by Cactoblastis cactorum [47], which represent methyl esters of 3-hydroxy fatty acids acylated at O-3 with another fatty acid (structures see Supporting Information File 1, Figure S8).

The isoprenyl fatty acid esters are not restricted to the genus Ithomia within the Ithomiini. Preliminary analysis also revealed that these esters are also constituents of the androconia of e.g. Hypothyris anastasia, Hyposcada illinissa, $H$. anchiala, or Melinaea menophilus. In contrast, 9-hydroxynonanoic acid derived acids and esters are currently only reported from Oleria [18].

\section{Conclusion}

In summary, we here describe a group of esters, never before reported in nature, 3-acetoxyacyl isoprenyl esters from Ithomia salapia. The large amounts of these esters in the androconia and the specialized enzymes needed to produce them seem to indicate a pheromonal function of them, especially at close range.

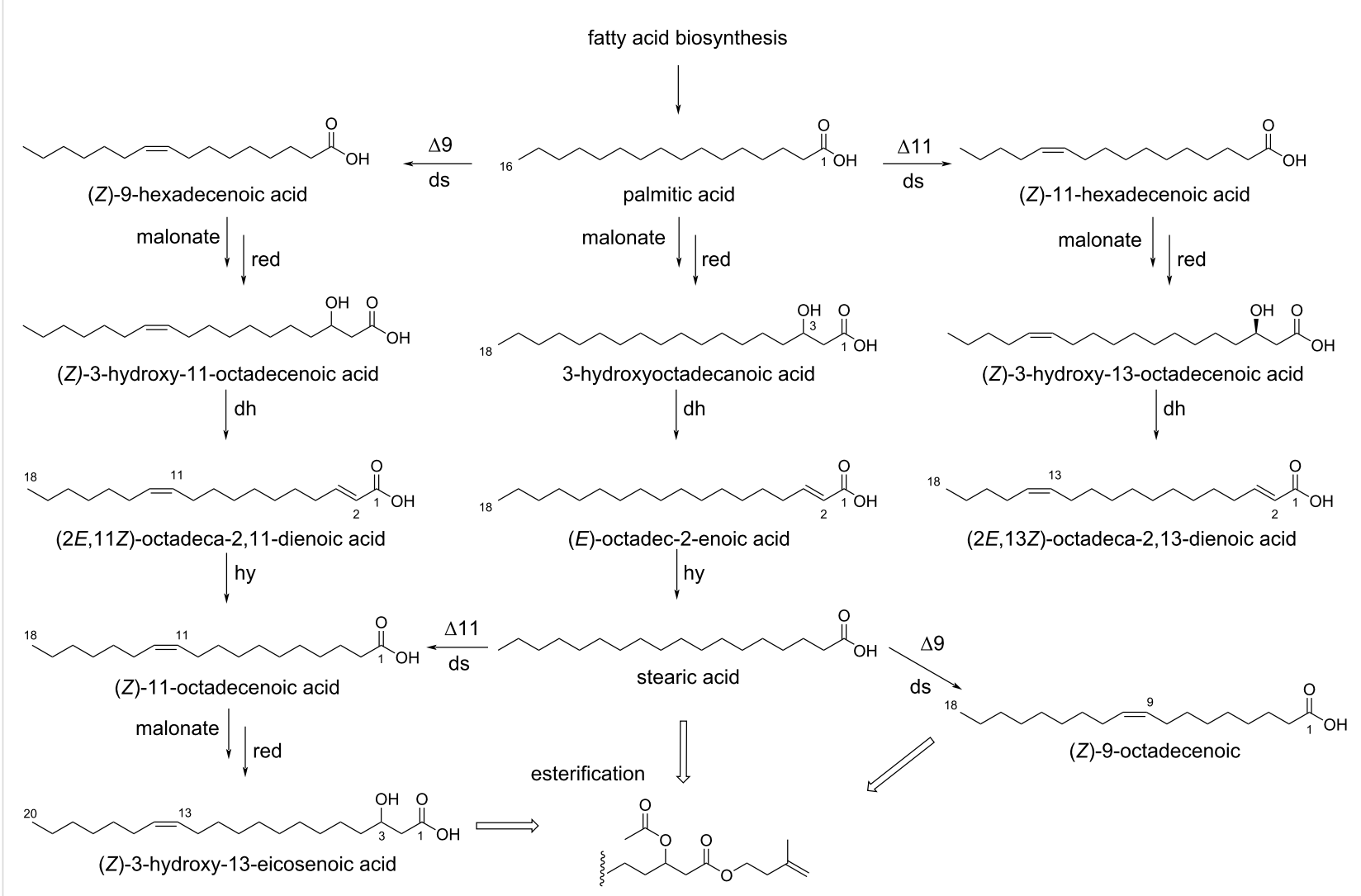

Scheme 5: Proposed biosynthetic pathway of fatty acids leading to the observed regioisomers of the isoprenyl esters. All acids shown were found in form of their isoprenyl esters. (Z)-9-Hexadecenoic acid is obtained from palmitic acid by a $\Delta 9$-desaturase (ds). Malonate elongation and reduction (red) leads to (Z)-3-hydroxy-11-octadecenoic acid, an intermediate of the fatty acid elongation cycle. The following elimination by a dehydratase (dh) leads to $(2 E, 11 Z)-2,11$-octadecadienoic acid and after hydrogenation (hy) to $(Z)$-11-octadecenoic acid, completing the $C_{2}$-elongation. $A$ second elongation furnishes (Z)-3-hydroxy-13-eicosenoic acid. Similarly, a $\Delta 11$-desaturase gives (Z)-11-hexadecenoic acid, (Z)-3-hydroxy-13-octadecenoic acid and (2E,13Z)-2,13-octadecadienoic acid. Both desaturases might also act on octadecanoic acid, but only the elongation of (Z)-11-octadecenoic acid can be observed, leading to (Z)-3-hydroxy-13-eicosenoic acid. The saturated 3-hydroxyoctadecanoic and stearic acids as well as ( $E$ )-2-octadecenoic acids are obtained similarly directly from palmitic acid. The proposed biosynthesis likely takes place in form of the conjugated acids, e.g., coenzyme $A$ esters or acyl carrier proteins. Finally, the acids are converted into the isoprenyl esters and the hydroxy acids are acylated. 
Differences in composition between the two subspecies suggest a possible role of the chemical bouquet in reproductive isolation, although other factors, such as wing color pattern, can also act as a reproductive barrier.

\section{Supporting Information}

\section{Supporting Information File 1}

Butterfly photos, mass, IR and NMR spectra, experimental procedures and analysis of individuals. [https://www.beilstein-journals.org/bjoc/content/ supplementary/1860-5397-16-228-S1.pdf]

\section{Acknowledgements}

We thank the Peruvian authorities and Dr. Gerardo Lamas (Museo de Historia Natural, Universidad Mayor de San Marcos) for research permits (236-2012-AG-DGFFSDGEFFS). We also thank Armando Silva-Vásquez and Stéphanie Galusser for their precious help in the field. Melanie McClure allowed usage of her Ithomia-photo in the graphical abstract.

\section{Funding}

We thank the Deutsche Forschungsgemeinschaft (DFG, Schu/ 12-1) and the French National Agency for Research (ANR) for financial support. This work was funded by the Deutsche Forschungsgemeinschaft (DFG) (Schu 984/12-1) and the French National Agency for Research (ANR) through the project SPECREP (ANR-14-CE02-0011).

\section{ORCID ${ }^{\circledR}$ iDs}

Florian Mann - https://orcid.org/0000-0003-0647-6942 Daiane Szczerbowski - https://orcid.org/0000-0002-3733-2960 Melanie McClure - https://orcid.org/0000-0003-3590-4002 Stefan Schulz - https://orcid.org/0000-0002-4810-324X

\section{Preprint}

A non-peer-reviewed version of this article has been previously published as a preprint: https://doi.org/10.3762/bxiv.2020.90.v1

\section{References}

1. Chazot, N.; Willmott, K. R.; Lamas, G.; Freitas, A. V. L.; Piron-Prunier, F.; Arias, C. F.; Mallet, J.; De-Silva, D. L.; Elias, M. Global Ecol. Biogeogr. 2019, 28, 1118-1132. doi:10.1111/geb.12919

2. Beccaloni, G. W. Trop. Lepid. 1997, 8, 103-124.

3. Müller, F. Trans. Entomol. Soc. London 1879, xx-xxix.

4. Gauthier, J.; de Silva, D. L.; Gompert, Z.; Whibley, A.; Houssin, C.; Le Poul, Y.; McClure, M.; Lemaitre, C.; Legeai, F.; Mallet, J.; Elias, M. Mol. Ecol. 2020, 29, 1328-1343. doi:10.1111/mec.15403
5. Dasmahapatra, K. K.; Lamas, G.; Simpson, F.; Mallet, J. Mol. Ecol. 2010, 19, 4283-4301. doi:10.1111/j.1365-294x.2010.04802.x

6. McClure, M.; Mahrouche, L.; Houssin, C.; Monllor, M.; Le Poul, Y.; Frérot, B.; Furtos, A.; Elias, M. J. Anim. Ecol. 2019, 88, 940-952. doi:10.1111/1365-2656.12975

7. Darragh, K.; Montejo-Kovacevich, G.; Kozak, K. M.; Morrison, C. R.; Figueiredo, C. M. E.; Ready, J. S.; Salazar, C.; Linares, M.; Byers, K. J. R. P.; Merrill, R. M.; McMillan, W. O.; Schulz, S.; Jiggins, C. D. Ecol. Evol. 2020, 10, 3895-3918. doi:10.1002/ece3.6079

8. González-Rojas, M. F.; Darragh, K.; Robles, J.; Linares, M.; Schulz, S.; McMillan, W. O.; Jiggins, C. D.; Pardo-Diaz, C.; Salazar, C. Proc. R. Soc. B 2020, 287, 20200587. doi:10.1098/rspb.2020.0587

9. Boppré, M. Naturwissenschaften 1986, 73, 17-26. doi:10.1007/bf01168801

10. Edgar, J. A.; Culvenor, C. C. J.; Pliske, T. E. J. Chem. Ecol. 1976, 2 , 263-270. doi:10.1007/bf00988276

11. Schulz, S.; Beccaloni, G.; Brown, K. S., Jr.; Boppré, M.; Freitas, A. V. L.; Ockenfels, P.; Trigo, J. R. Biochem. Syst. Ecol. 2004, 32, 699-713. doi:10.1016/j.bse.2003.12.004

12. Schulz, S. Liebigs Ann. Chem. 1992, 829-834. doi:10.1002/jlac.1992199201137

13. Edgar, J. A. Philos. Trans. R. Soc., B 1975, 272, 467-476. doi:10.1098/rstb.1975.0097

14. Schulz, S. Eur. J. Org. Chem. 1998, 13-20. doi:10.1002/(sici)1099-0690(199801)1998:1<13::aid-ejoc13>3.0.co;2-r

15. Honda, Y.; Honda, K.; Ômura, H. J. Insect Physiol. 2006, 52, 1043-1053. doi:10.1016/j.jinsphys.2006.07.003

16. Schneider, D.; Boppré, M.; Zweig, J.; Horsley, S. B.; Bell, T. W.; Meinwald, J.; Hansen, K.; Diehl, E. W. Science 1982, 215, 1264-1265. doi:10.1126/science.215.4537.1264

17. Culvenor, C. C. J.; Edgar, J. A. Experientia 1972, 28, 627-628. doi:10.1007/bf01944939

18. Stamm, P.; Mann, F.; McClure, M.; Elias, M.; Schulz, S. J. Chem. Ecol. 2019, 45, 768-778. doi:10.1007/s10886-019-01100-5

19. Schulz, S.; Francke, W.; Edgar, J.; Schneider, D. Z. Naturforsch., C: J. Biosci. 1988, 43, 99-104. doi:10.1515/znc-1988-1-219

20. Jones, R. V. H.; Sutherland, M. D. Chem. Commun. 1968, 1229-1230. doi:10.1039/c19680001229

21. Kodama, M.; Yokoo, S.; Matsuki, Y.; Itô, S. Tetrahedron Lett. 1979, 20 , 1687-1690. doi:10.1016/s0040-4039(01)93624-x

22. Baer, P.; Rabe, P.; Citron, C. A.; de Oliveira Mann, C. C.; Kaufmann, N.; Groll, M.; Dickschat, J. S. ChemBioChem 2014, 15 , 213-216. doi:10.1002/cbic.201300708

23. Ayasse, M.; Engels, W.; Hefetz, A.; Lübke, G.; Francke, W. Z. Naturforsch., C: J. Biosci. 1990, 45, 709-714. doi:10.1515/znc-1990-0623

24. Duffield, R. M.; Fernandes, A.; Lamb, C.; Wheeler, J. W.; Eickwort, G. C. J. Chem. Ecol. 1981, 7, 319-331. doi:10.1007/bf00995755

25. Scribe, P.; Guezennec, J.; Dagaut, J.; Pepe, C.; Saliot, A. Anal. Chem. (Washington, DC, U. S.) 1988, 60, 928-931. doi:10.1021/ac00160a019

26. Schulze, T.; Weldon, P. J.; Schulz, S. Z. Naturforsch., C: J. Biosci. 2017, 72, 265-275. doi:10.1515/znc-2017-0006

27. Flachsbarth, B.; Fritzsche, M.; Weldon, P. J.; Schulz, S. Chem. Biodiversity 2009, 6, 1-37. doi:10.1002/cbdv.200800265

28. Ryhage, R.; Stenhagen, E. Ark. Kemi 1960, 15, 545-574.

29. Sémon, E.; Ferary, S.; Auger, J.; Le Quéré, J. L. J. Am. Oil Chem. Soc. 1998, 75, 101-105. doi:10.1007/s11746-998-0018-7 
30. Schlawis, C.; Schulz, S. Nat. Prod. Rep. 2020. doi:10.1039/d0np00013b

31. More, J. D.; Finney, N. S. Org. Lett. 2002, 4, 3001-3003. doi:10.1021/ol026427n

32. Holmquist, C. R.; Roskamp, E. J. J. Org. Chem. 1989, 54, 3258-3260. doi:10.1021/jo00275a006

33. Otera, J.; Yano, T.; Kawabata, A.; Nozaki, H. Tetrahedron Lett. 1986, 27, 2383-2386. doi:10.1016/s0040-4039(00)84535-9

34. Huang, G.; Hollingsworth, R. I. Tetrahedron: Asymmetry 1998, 9 , 4113-4115. doi:10.1016/s0957-4166(98)00441-8

35. König, W. A.; Gehrcke, B.; Pete, M. G.; Prestwich, G. D. Tetrahedron: Asymmetry 1993, 4, 165-168. doi:10.1016/s0957-4166(00)82328-9

36. Neumann, A.; Patzelt, D.; Wagner-Döbler, I.; Schulz, S. ChemBioChem 2013, 14, 2355-2361. doi:10.1002/cbic.201300424

37. Schulz, S.; Estrada, C.; Yildizhan, S.; Boppré, M.; Gilbert, L. E. J. Chem. Ecol. 2008, 34, 82-93. doi:10.1007/s10886-007-9393-z

38. Yildizhan, S.; van Loon, J.; Sramkova, A.; Ayasse, M.; Arsene, C.; ten Broeke, C.; Schulz, S. ChemBioChem 2009, 10, 1666-1677. doi:10.1002/cbic.200900183

39. Estrada, C.; Schulz, S.; Yildizhan, S.; Gilbert, L. E. Evolution 2011, 65, 2843-2854. doi:10.1111/j.1558-5646.2011.01352.x

40. Wang, H.-L.; Brattström, O.; Brakefield, P. M.; Francke, W.; Löfstedt, C. J. Chem. Ecol. 2014, 40, 549-559. doi:10.1007/s10886-014-0452-y

41. Bacquet, P. M. B.; Brattström, O.; Wang, H.-L.; Allen, C. E.; Löfstedt, C.; Brakefield, P. M.; Nieberding, C. M. Proc. R. Soc. B 2015, 282, 20142734. doi:10.1098/rspb.2014.2734

42. Jurenka, R. Insect pheromone biosynthesis. In The Chemistry of Pheromones and Other Semiochemicals I; Schulz, S., Ed.; Topics in Current Chemistry, Vol. 239; Springer: Berlin, Heidelberg, 2004; pp 97-132. doi:10.1007/b95450

43. Liénard, M. A.; Hagström, Å. K.; Lassance, J.-M.; Löfstedt, C. Proc. Natl. Acad. Sci. U. S. A. 2010, 107, 10955-10960. doi:10.1073/pnas.1000823107

44. Meinwald, J.; Meinwald, Y. C. J. Am. Chem. Soc. 1966, 88, 1305-1310. doi:10.1021/ja00958a039

45. Mann, F.; Vanjari, S.; Rosser, N.; Mann, S.; Dasmahapatra, K. K.; Corbin, C.; Linares, M.; Pardo-Diaz, C.; Salazar, C.; Jiggins, C.; Schulz, S. J. Chem. Ecol. 2017, 43, 843-857. doi:10.1007/s10886-017-0867-3

46. Murphy, B. T.; Cao, S.; Norris, A.; Miller, J. S.; Ratovoson, F.; Andriantsiferana, R.; Rasamison, V. E.; Kingston, D. G. I. Planta Med. 2006, 72, 1235-1238. doi:10.1055/s-2006-947192

47. Rossi, F. M.; Rojas, D.; Cervasio, D. A.; Posillico, J.; Parella, K.; Fitzgerald, T. D. Chemoecology 2020, 30, 245-253. doi:10.1007/s00049-020-00314-4

\section{License and Terms}

This is an Open Access article under the terms of the Creative Commons Attribution License (https://creativecommons.org/licenses/by/4.0). Please note that the reuse, redistribution and reproduction in particular requires that the authors and source are credited.

The license is subject to the Beilstein Journal of Organic Chemistry terms and conditions: (https://www.beilstein-journals.org/bjoc)

The definitive version of this article is the electronic one which can be found at:

https://doi.org/10.3762/bjoc. 16.228 